Noorhidawati Abdullah, Samuel Chu, Sandhya Rajagopal, Abigail Tung and Yeung Kwong-Man

\title{
Exploring Libraries' Efforts in Inclusion and Outreach Activities Using Social Media
}

\begin{abstract}
The main purpose of this study was to investigate the use of social media tools to enhance inclusion and outreach activities in libraries. The study also examined the existence of policies that encouraged the use of social media and the challenges that libraries face when integrating social media into their services. Invitations to participate in a survey were sent to 110 libraries in Greater China, Switzerland, United States of America, United Kingdom, Australia and New Zealand to investigate the use of social media tools in their inclusion/outreach programmes and librarians' perceptions of their usefulness. Libraries were selected on the basis of indicating on their websites that they used social media. From the 110 libraries that were invited to participate in the survey, 28 responses were received and analysed. Among these, academic libraries made up $68 \%$ of the respondents, and the remaining $32 \%$ were from public libraries. The findings indicated that the libraries had already incorporated social media tools into their services, and, to some extent, for inclusion/outreach activities. In general, participants in this study indicated an acknowledgement of the benefits of using social media and an inclination to apply social media in the future, although the libraries and librarians faced the challenge of equipping themselves well in order to keep abreast of these technologies. The study highlighted the lack of specific policies that clarified the responsibilities of libraries in promoting social inclusion. Institutionalizing specific policies on the use of social media tools in libraries could be done either using a top-down and/or a bottom-up approach.
\end{abstract}

Dr. Noorhidawati Abdullah, Senior Lecturer, Department of Library and Information Science, Faculty of Computer Science and Information Technology, University of Malaya, Kuala Lumpur, Malaysia, E-mail: noorhidawati@um.edu.my

Dr. Samuel Chu, Associate Professor and Head of Division of Information and Technology Studies, Faculty of Education, University of Hong Kong, Hong Kong, China, E-mail: samchu@hku.hk

Sandhya Rajagopal, PhD Student: E-mail: sandhyaraj@gmail.com, Abigail Tung, MLIM Student: E-mail: jackalpleace@yahoo.com.hk, Yeung Kwong-Man, MLIM Student: E-mail: maniyeung@yahoo.com. hk, Faculty of Education, University of Hong Kong, Hong Kong, China
Keywords: library inclusion, library outreach, social media, library 2.0, academic libraries, public libraries, China, Hong Kong, Taiwan, Switzerland, United States of America, United Kingdom, Australia, New Zealand

DOI 10.1515/libri-2014-0055

Received May 14, 2014; revised October 27, 2014; accepted November 5, 2014

\section{Introduction}

The United Nations defines an inclusive society as "a society for all”, where every individual has rights, responsibilities and an active role to play in the society (United Nations 1995). Libraries support social inclusion by promoting equal opportunities and accommodating diversity to facilitate the active participation of each individual in library programmes and services as stated by the Department of Economic and Social Affairs-United Nations in 2012. One mechanism instituted by libraries to support social inclusion is through outreach programmes. These programmes are used as channels to "reach out to their users, to encourage use of the library and its resources, and to promote a positive image on campus and often in the community" (Carter and Seaman 2011, 164) and are believed to empower libraries to be agents of social inclusion.

Muddiman et al. $(2001,157)$ examined the ability of libraries to embrace inclusion and reported that, "public libraries have the potential to play a key role in tackling social exclusion, but in order to make a real difference they will need to undergo rapid transformation and change." Alongside a host of processes that promote social inclusion, information and communication technologies (ICTs) and social media tools have been identified as some of the new instruments that could be used ( $\mathrm{Chu}$ and $\mathrm{Du}$ 2013; van Winden 2001; Zohoorian-Fooladi and Abrizah 2014a).

In recent years, the Internet has undergone a transformation, from being a static repository of information to being a socially interactive Web. The development of what has been termed Library 2.0 has introduced the collaborative development of content in libraries using social media instruments such as Facebook, Twitter and Delicious (Bolan, 
Canada, and Cullin 2007). Such social media websites are thought to comprise a form of technology that creates outreach opportunities for libraries (Dickson and Holley 2010). The main purpose of this study is to investigate how different academic and public libraries around the world use social media for social inclusion and outreach activities. The findings of this study contribute to a better understanding of social media as a strategy for libraries to promote "a society for all” as defined by United Nations.

\section{Literature Review}

Train, Dalton, and Elkin (2000) noted that the key concept of social inclusion is equivalent to the philosophy of public library services, which is to promote equal opportunities for all. They further stated that, in attempting to apply such a mandate, public libraries have confronted the challenges of social deprivation and disadvantage through outreach work with excluded communities. Dennis (2012), in addition, suggested that outreach activities in a library should include and reach audiences who may not be able to visit the library or be exposed to library resources and services physically. Therefore, it can be summarized that there exist various library outreach programmes, some of which are specifically intended to promote social inclusion.

\section{Outreach Programmes in Libraries}

Conventionally, libraries have used outreach programmes to connect with the communities they serve. For example, Dennis (2012) studied academic libraries and identified outreach initiatives such as "Bathroom Stall Newsletters", "Novel Writing Month”, “African American Heritage and Cultural Read In”, Webinars, iPad Forum and Annual Technology Conference. It appears that a variety of initiatives are considered by librarians as outreach programmes and are primarily directed towards involving patrons in library-initiated activities. Similarly, Carter and Seaman (2011) noted that library outreach initiatives tend to be aimed at promoting library services.

\section{Social Inclusion Programmes in Libraries}

In general when libraries promote social inclusion, they contribute to creating a community that supports diversity. For example, the library's role in social inclusion is apparent in children's services (e.g. Homework Clubs) that support the development of children and young adults, by providing them with a safe, non-threatening environment and opportunities for growth at their own pace (Train, Dalton, and Elkin 2000). Another example is the library inclusion programme in academic library settings in Malaysia, which is intended for disabled people, particularly visually impaired students, and which involves special study carrels and student volunteers (Nahid Bayat and Zainab 2013; Nahid Bayat, Zainab, and Abdullah 2014). The study conducted by Nahid Bayat, Zainab, and Abdullah (2014) emphasized that an effective inclusion programme should integrate both physical amenities and social services.

The importance of the library's role in social inclusion has also been stated in government policy statements, such as in the UK, where libraries are deemed to have "an important role to play in helping to combat social exclusion and promote lifelong learning" (U.K. DCMS 1999, 7). However, more recently, the governments in the UK and the USA are closing their public libraries due to the economic downturn. The Guardian newspaper, for example, reported that more than 200 libraries had closed in the UK in 2012 (Flood 2012), and the number was predicted to grow to 1,000 by 2016 (Bury 2013). Similarly, in other parts of the world such as the USA, public libraries are facing a crisis of budget cuts and branch closures (Kavner 2011).

\section{Social Media in Libraries}

With an increasing number of younger adults becoming Internet users, the popularity of Social Network Services/ Sites (SNSs) has also increased dramatically. Enders and Wineland $(2012,16)$ stated that, "to lack a social media presence in 2012 is like not having a telephone twenty years ago.” At present, students are likely to engage with entities that utilize these currently popular forms of technology. Because of this, libraries, too, now utilize different forms of social media for different purposes in an attempt to reach the younger generation. Libraries have adopted social media tools such as Facebook, blogs, wikis and Twitter (Browne and Rooney-Browne 2008; Chu and Du 2013; Loudon and Hall 2010; Zohoorian-Fooladi and Abrizah 2014a; Huang, Chu, and Chen in press).

Although SNSs such as Facebook and MySpace are well known in the West, such as in the USA, Orkut is widely used in the Asia Pacific region and South America, whilst Bebo is more popular in Australia and Europe (Chu and $\mathrm{Du}$ 2013). In China, on the other hand, Weibo (the Chinese version of Twitter) and Renren (the Chinese 
version of Facebook) are predominantly used. It has been claimed that the use of social media by libraries has enhanced efforts to promote inclusion and outreach (Dickson and Holley 2010). Although a number of associated problems have arisen, such as difficulties in assessing the actual impact of social media in promoting library services and in deciding what social media tools are the most suitable for users, Enders and Wineland $(2012,16)$ pointed out that, "a social media policy to guide postings and set limits on use can address several of these concerns.”

\section{Literature Gap}

Despite such suggestions, studies that contribute to the understanding of the use of social media tools for the purpose of increasing social inclusion in libraries remain scarce. Connell (2009), in a survey of college students, analysed the perspective of users and their attitudes towards interaction with librarians via Facebook and MySpace as a means of outreach. The students noted the pros and cons of employing these two particular social networking tools to reach out to students and suggested ways to use social media as instruments of library outreach. Kelly et al. (2009), in discussing the risks and benefits of using Library 2.0, provided perspectives and justification for libraries that are currently implementing social media tools to enhance library activities. Although the authors suggested social inclusion as a means to resolve accessibility issues, no investigation into such an application has been carried out. Conversely, Sekyere (2009) expressed scepticism about the application of social media tools for outreach programmes, especially Facebook. While there is a copious amount of literature on the types of social media tools that can be used in libraries for various activities (Kroski 2007), and on the application of social media tools such as Twitter (Milstein 2009), Facebook (Connell 2009; Mack et al. 2007; Mathews 2006) and MySpace, this literature is primarily concerned with potential or existent applications of social media for outreach purposes in libraries. Research on the benefits gained and challenges faced by libraries when social media tools are used for outreach/social inclusion activities remains limited. In addition, most of the studies in the literature reported on social media usage in a single institution or country/region (e.g. Dennis 2012; Dickson and Holley 2010; Phillips 2011). As no study had reported on cross-countries or cross-region initiatives to represent an international population, this study was conducted to fill the gap.

\section{Research Methods}

With the objective being to fill the literature gap identified above, a survey was conducted among academic and public libraries in order to investigate the use of social media tools for social inclusion/outreach purposes. The following research questions were asked:

1. What types of social media do the surveyed libraries use?

2. Is social media used for enhancing inclusion/outreach activities?

3. What is the perceived usefulness of applying social media for inclusion/outreach?

4. Do the libraries have policies to encourage social inclusion and outreach?

5. What are the benefits and challenges associated with using social media in libraries?

The survey invitations were forwarded to libraries that have been using social media tools as reflected in their official websites. The survey was conducted from July to October 2012. From the 110 libraries that were invited to participate in the survey, 28 responses were received and analysed. This resulted in a $25 \%$ response rate, which is typical for an online survey as stated by Gravetter and Forzano (2008), who mentioned that a typical response rate for an online survey is only about $18 \%$. Among the 28 responses, academic libraries made up $68 \%$ of the respondents, and the remaining $32 \%$ were from public libraries. These libraries were located in Greater China (the People's Republic of China, the Hong Kong Special Administrative Region and Taiwan) and in non-Chinesespeaking countries (Australia, New Zealand, Switzerland, United Kingdom and United States of America), providing information from an international sample.

One member of each participating library was invited to complete a self-administered questionnaire consisting of eight questions. The first four questions elicited information about the social media tools most commonly employed by the libraries for varied purposes, and how long these tools had been used. The last four questions were open-ended and requested participants to provide details of the benefits and advantages derived, the challenges and difficulties faced and existing policy statements, if any. The distribution of the responding libraries between Chinese-speaking and other countries and their types is shown in Table 1.

Responses to close-ended questions were analysed quantitatively and were supported by participants' responses to open-ended questions. Where a five-point Likert-type scale was used, responses were summarized 
Table 1: Composition of the surveyed population $(n=28)$.

\begin{tabular}{lll}
\hline & Academic libraries & Public libraries \\
\hline Chinese-speaking countries & $10(\mathrm{R} 18, \mathrm{R} 20, \mathrm{R} 21, \mathrm{R} 22, \mathrm{R} 23, \mathrm{R} 24, \mathrm{R} 25, \mathrm{R} 26, \mathrm{R} 27, \mathrm{R} 28)$ & 1 $^{\star}(\mathrm{R} 19)$ \\
Non-Chinese-speaking countries & 9 (R1, R3, R4, R5, R6, R14, R15, R16, R17) & 8 (R2, R7, R8, R9, R10, R11, R12, R13) \\
\hline
\end{tabular}

Note: *This institution is a repository, but is considered a public library for the purpose of this research.

using descriptive statistics. Respondent libraries were coded as R1 to R28, and the corresponding librarian representatives were labelled L1 to L28. A number of responses to open-ended questions are reported in this paper.

\section{Findings}

\section{Types of Social Media Tools Used in Libraries}

For this particular question, participants were asked to rate all the media tools they had used in their libraries. Overall, 22 of the 28 libraries had used at least two or more social media tools for more than 4 years. Table 2 shows the types of social media tools used by academic and public libraries, and the duration of use in years as indicated by the 5 points of the rating scale $(1=$ Never; $2=<1$ year; $3=1-2$ years;

Table 2: The usage of social media tools in libraries $(n=28)$.

\begin{tabular}{lrrr}
\hline Social media tools & Mode & Mean & SD \\
\hline Academic libraries & & & \\
Blogs & 5 & 4.1 & 1.47 \\
RSS & 4 & 4.3 & 1.29 \\
Facebook & 3 & 3.0 & 1.29 \\
Twitter & 3 & 2.4 & 1.46 \\
Others (Netvibes, LibraryThing & 2 & 2.9 & 1.45 \\
Pinterest, LibGuide) & & & \\
Flickr & 1 & 2.5 & 1.71 \\
YouTube & 1 & 2.6 & 1.67 \\
Wiki & 1 & 2.6 & 1.80 \\
Delicious & 1 & 1.6 & 1.34 \\
Public libraries & & & \\
Flickr & 5 & 3.7 & 1.66 \\
Blogs & 4 & 3.6 & 1.59 \\
RSS & 4 & 3.6 & 1.30 \\
Facebook & 4 & 3.3 & 1.50 \\
YouTube & 3 & 3.4 & 1.24 \\
Twitter & 3 & 3.3 & 1.12 \\
Others (Pinterest, Historypin, Foursquare) & 2 & 2.5 & 1.00 \\
Wiki & 1 & 2.3 & 1.66 \\
Delicious & 1 & 1.5 & 1.41 \\
\hline
\end{tabular}

Note: Rating scale: $1=$ Never; $2=<1$ year; $3=1-2$ years; $4=3-4$ years; $5=>4$ years.
$4=3-4$ years; $5=>4$ years). In general, the tools that had been used longer by the participants were blogs (academic libraries; mean value: 4.1), and Flickr (public libraries; mean value: 3.7). This was followed by RSS for academic libraries and blogs for public libraries.

\section{Social Media in Inclusion/Outreach Programmes in Libraries}

Table 3 shows the types of social media tools that were employed in academic and public libraries for various activities, with an indication of whether they were applied for inclusion, for outreach or for both purposes. Social media tools in the academic libraries were most frequently used for both inclusion and outreach purposes and involved in activities such as library tours, library exhibitions and book recommendations, while library news postings were mainly used for outreach purposes. For the public libraries, on the other hand, library news postings were most frequently used for both inclusion and outreach purposes, while book recommendations were mainly used for outreach purposes.

For both academic and public libraries, the primary library inclusion and/or outreach activity for which social media tools were used was library news posting. Facebook was the most frequently applied SM tool and was used for book talks, exhibitions, virtual references, book recommendations and library news postings. The second most often used tool was the blog, which was employed for online library user guides and book recommendations in both academic and public libraries. YouTube had been adopted by a number of academic libraries for library tours, and Flickr was used by public libraries for exhibitions. No social media tools were used by any of the participants for storytelling and inclusive storytelling, a finding that was probably attributable to the small number of responses from the public libraries. Inclusive storytelling, which is designed specifically to develop narrative skills in children who have difficulties in learning and communication, is normally used in public libraries. 
Table 3: Library activities that used social media tools $(n=28)$.

\begin{tabular}{lll}
\hline Library activities & Most frequent social media tools used & Most frequent purpose of usage \\
\hline $\begin{array}{l}\text { Academic libraries } \\
\text { Library tour }\end{array}$ & \\
Book talks & YouTube (5) & \\
Exhibitions & Facebook (6) & Inclusion and outreach (6) \\
Virtual references & Facebook (8) & Inclusion and outreach (5) \\
Online library user guide & Facebook (3) & Inclusion and outreach (6) \\
Book recommendations & Blogs (4) & Outreach (3) \\
Library news posting & Facebook (4) & Outreach (5) \\
Public libraries & Facebook (10) & Inclusion and outreach (6) \\
Book talks & & Outreach (8) \\
Exhibitions & Facebook (3) & \\
Virtual references & Flickr (2) & Outreach (3) \\
Book recommendations & Facebook (2) & Inclusion and outreach (3) \\
Library news posting & Blog (4) & Inclusion and outreach (3) \\
Others & Facebook (5) & Outreach (4) \\
\hline
\end{tabular}

Note: Numbers in brackets refer to the number of responses using SM tools for inclusion/outreach/both.

The libraries that had not adopted social media technologies had, however, been implementing inclusion and/or outreach programmes for many years without them. For example, library news postings, exhibitions, library tours and online library guides were the most popular activities that had been conducted for more than 4 years, as shown in Table 4.

\section{Perceived Usefulness of Social Media Tools for Inclusion and/or Outreach Activities}

Table 5 compares respondents' perceptions of the usefulness of social media tools in academic and public libraries for different inclusion/outreach activities based

Table 4: Library activities for which social media tools had not been used $(n=28)$.

\begin{tabular}{lrrr}
\hline Outreach/inclusion activities & Mode & Mean & SD \\
\hline Library news posting & 5 & 5.0 & 0.00 \\
Others & 5 & 5.0 & 0.00 \\
Exhibition & 5 & 4.6 & 1.26 \\
Online library user guide & 5 & 4.6 & 1.09 \\
Library tour & 5 & 4.4 & 1.45 \\
Book recommendation & 5 & 3.7 & 1.86 \\
Virtual reference & 5 & 3.4 & 1.93 \\
Book talks & 1 & 1.8 & 1.69 \\
Storytelling sessions & 1 & 1.6 & 1.43 \\
Inclusive story times (including children with & 1 & 1.2 & 0.87 \\
special needs) & & & \\
\hline
\end{tabular}

Note: Rating scale: $1=$ never; $2=<1$ year; $3=1-2$ years; $4=3-4$ years; $5=>4$ years. on the five-point Likert-type scale $(1=$ strongly disagree; 2 = disagree; 3 = neutral; $4=$ agree; $5=$ strongly agree). In the academic libraries, Twitter, blogs and Facebook were the most preferred tools for library activities, with all three being quite popular means of posting library news, followed by YouTube. For public libraries, the most favoured SM tools were blogs and RSS feeds, closely followed by Twitter. Twitter was highly rated for Library news postings. YouTube, on the other hand, was generally the preferred tool for virtual library tours and exhibitions. RSS feeds and Twitter were rated highly for use with book recommendations and library news postings. At the other end, Delicious and wiki were the least preferred tools in both types of libraries.

It is important to note from the findings that, although a number of respondents in the interview sessions opined that storytelling should be used to serve children's needs in a particular social inclusion programme, the respondents did not report any actual usage of social media tools for storytelling activities, as shown in Table 4. Nevertheless, a few librarians (one response from an academic library and two responses from public libraries) were in agreement that social media could be utilized for storytelling activities, mainly using YouTube, Facebook and blogs as platforms (as shown in Table 5).

This indicates that storytelling is still relevant in academic library settings. Librarians and/or library patrons could create a real story about library services and available facilities in the form of video montage and share the video via YouTube, Facebook and blogs to reach an audience beyond the physical location of the library. 
Table 5: Comparison of perceptions of usefulness in academic and public libraries.

\begin{tabular}{|c|c|c|c|c|c|c|c|c|c|c|}
\hline $\begin{array}{l}\text { Social } \\
\text { media } \\
\text { tools }\end{array}$ & & $\begin{array}{r}\text { Library } \\
\text { tour }\end{array}$ & $\begin{array}{r}\text { Book } \\
\text { talks/book } \\
\text { discussions }\end{array}$ & Storytelling & Exhibitions & $\begin{array}{r}\text { Inclusive } \\
\text { story times }\end{array}$ & $\begin{array}{r}\text { Virtual } \\
\text { reference } \\
\text { services }\end{array}$ & $\begin{array}{r}\text { Online library } \\
\text { user guide }\end{array}$ & $\begin{array}{r}\text { Book } \\
\text { recommendation }\end{array}$ & $\begin{array}{r}\text { Library } \\
\text { news } \\
\text { posting }\end{array}$ \\
\hline \multirow[t]{2}{*}{ Blogs } & $\begin{array}{l}\text { Academic libraries } \\
(n=16)\end{array}$ & 3.4(5) & $4.3(7)$ & 4.0(1) & $3.9(7)$ & $1.0(1)$ & $3.3(6)$ & $4.2(8)$ & $4.2(6)$ & 4.3(14) \\
\hline & $\begin{array}{l}\text { Public libraries } \\
(n=8)\end{array}$ & $3.8(4)$ & $3.8(5)$ & $4.0(2)$ & $4.0(5)$ & $4.0(2)$ & $4.0(3)$ & 4.3(4) & 4.4(5) & $4.7(8)$ \\
\hline \multirow[t]{2}{*}{ Facebook } & $\begin{array}{l}\text { Academic libraries } \\
(n=14)\end{array}$ & $3.6(7)$ & 4.2(9) & $4.0(1)$ & 4.3(9) & $1.0(1)$ & $3.9(8)$ & $3.6(8)$ & $4.2(6)$ & 4.4(13) \\
\hline & $\begin{array}{l}\text { Public libraries } \\
(n=7)\end{array}$ & $3.8(5)$ & $4.0(4)$ & $4.0(2)$ & 4.4(5) & $4.0(2)$ & $3.8(7)$ & $4.3(3)$ & $4.0(4)$ & $4.9(7)$ \\
\hline \multirow[t]{2}{*}{ Flickr } & $\begin{array}{l}\text { Academic libraries } \\
(n=6)\end{array}$ & 3.3(3) & $2.3(3)$ & 4.0(1) & $3.3(4)$ & $1.0(1)$ & $1.5(2)$ & $1.5(2)$ & $1.0(1)$ & $1.3(3)$ \\
\hline & $\begin{array}{l}\text { Public libraries } \\
(n=5)\end{array}$ & 3.2(5) & $3.0(4)$ & $3.0(2)$ & $5.0(5)$ & $3.5(2)$ & $3.0(3)$ & $2.3(4)$ & $2.5(2)$ & $3.8(4)$ \\
\hline \multirow[t]{2}{*}{ Delicious } & $\begin{array}{l}\text { Academic libraries } \\
(n=6)\end{array}$ & 1.3(3) & $1.7(3)$ & $1.0(1)$ & $1.0(1)$ & $1.0(1)$ & $1.7(3)$ & $2.0(3)$ & $1.0(1)$ & $2.0(3)$ \\
\hline & $\begin{array}{l}\text { Public libraries } \\
(n=2)\end{array}$ & $1.0(1)$ & $2.0(2)$ & $3.0(1)$ & $2.0(2)$ & $3.0(1)$ & $3.0(1)$ & $3.0(2)$ & $3.0(1)$ & $3.0(2)$ \\
\hline \multirow[t]{2}{*}{ YouTube } & $\begin{array}{l}\text { Academic libraries } \\
(n=10)\end{array}$ & 4.1(8) & $3.7(6)$ & $5.0(1)$ & 4.5(2) & $1.0(1)$ & $2.7(3)$ & $3.6(5)$ & 4.0(1) & $2.3(3)$ \\
\hline & $\begin{array}{l}\text { Public libraries } \\
(n=6)\end{array}$ & $4.8(4)$ & $3.0(4)$ & $4.0(2)$ & $4.0(4)$ & $4.0(2)$ & $3.8(4)$ & $3.8(4)$ & $4.0(2)$ & $4.0(3)$ \\
\hline \multirow[t]{2}{*}{ RSS } & $\begin{array}{l}\text { Academic libraries } \\
(n=9)\end{array}$ & $2.0(3)$ & $2.3(3)$ & $1.0(1)$ & $2.0(2)$ & $1.0(1)$ & $2.7(3)$ & $2.7(3)$ & $4.0(3)$ & 4.1(7) \\
\hline & $\begin{array}{l}\text { Public libraries } \\
(n=6)\end{array}$ & $3.7(3)$ & $3.7(3)$ & $4.0(2)$ & $4.0(3)$ & $4.0(2)$ & $4.0(2)$ & 4.3(3) & $4.0(3)$ & $4.8(5)$ \\
\hline \multirow[t]{2}{*}{ Twitter } & $\begin{array}{l}\text { Academic libraries } \\
(n=9)\end{array}$ & $3.8(5)$ & $3.8(6)$ & $3.0(1)$ & $3.8(4)$ & $1.0(1)$ & $3.3(4)$ & $3.3(6)$ & $4.3(3)$ & 4.2(9) \\
\hline & $\begin{array}{l}\text { Public libraries } \\
(n=7)\end{array}$ & $3.0(4)$ & $4.0(4)$ & $4.0(2)$ & $4.0(4)$ & $4.0(2)$ & $4.0(4)$ & 4.3(3) & $4.0(4)$ & $5.0(7)$ \\
\hline \multirow[t]{2}{*}{ Wiki } & $\begin{array}{l}\text { Academic libraries } \\
(n=5)\end{array}$ & $2.3(3)$ & $2.3(3)$ & $1.0(1)$ & $1.0(1)$ & $1.0(1)$ & $2.7(3)$ & $2.8(4)$ & $1.0(1)$ & $2.0(2)$ \\
\hline & $\begin{array}{l}\text { Public libraries } \\
(n=2)\end{array}$ & $2.0(2)$ & $2.5(2)$ & $2.5(2)$ & $2.5(2)$ & $2.5(2)$ & $2.5(2)$ & $2.5(2)$ & $2.5(2)$ & $3.5(2)$ \\
\hline
\end{tabular}

Note:

(i) $M=$ Mean response for the level of agreement for the usefulness of the SM tools. The responses were based on the 5 points of Likert scale: $1=$ strongly disagree; 2 = disagree; $3=$ neutral; 4 = agree; $5=$ strongly agree.

(ii) Numbers in bracket refers to the number of responses for the usefulness of social media tools for library activities.

\section{Perceived Usefulness of Social Media Tools across Libraries among Chinese- and Non-Chinese-Speaking Participants}

Table 6 compares the degree to which respondents agreed about the usefulness of SM tools in non-Chineseand Chinese-speaking countries. In the non-Chinesespeaking sample comprising 16 libraries, Twitter, RSS feeds and Facebook were rated most positively (mean score over 4.7) for posting library news, closely followed by blogs. Facebook was quite popular for exhibitions too. YouTube was by far the most popular tool for library tours in these regions also. These few tools were more popular than any other SM tools.
For the 11 libraries located in Chinese-speaking countries, most of the participants agreed that blogs were useful primarily for library news postings, book recommendations and online library user guides, while Facebook was the preferred tool for book talks and exhibitions. In these libraries, YouTube was the most popular tool for library tours. Similar to the non-Chinese-speaking group, the Chinese-speaking group perceived RSS feeds as useful for library news postings. According to the mean ratings for both non-Chinese- and Chinesespeaking countries/regions, wikis and Delicious were rated the least useful for outreach/inclusion activities at the libraries, while libraries in Chinese-speaking countries/regions in general gave low ratings for Twitter and 
Table 6: Comparison of perceptions of usefulness among Chinese- and non-Chinese-speaking participants across libraries.

\begin{tabular}{|c|c|c|c|c|c|c|c|c|c|c|}
\hline $\begin{array}{l}\text { Social } \\
\text { media } \\
\text { tools }\end{array}$ & & $\begin{array}{r}\text { Library } \\
\text { tour }\end{array}$ & $\begin{array}{r}\text { Book talks/ } \\
\text { book } \\
\text { discussions }\end{array}$ & Storytelling & Exhibitions & $\begin{array}{r}\text { Inclusive } \\
\text { story } \\
\text { times }\end{array}$ & $\begin{array}{r}\text { Virtual } \\
\text { reference } \\
\text { services }\end{array}$ & $\begin{array}{r}\text { Online } \\
\text { library user } \\
\text { guide }\end{array}$ & $\begin{array}{r}\text { Book } \\
\text { recommendation }\end{array}$ & $\begin{array}{r}\text { Library } \\
\text { news } \\
\text { posting }\end{array}$ \\
\hline \multirow[t]{2}{*}{ Blogs } & $\begin{array}{l}\text { Non-Chinese } \\
\text { countries }(n=16)\end{array}$ & $4(6)$ & 4.1(8) & $4(2)$ & 4.1(8) & $4(2)$ & $4(5)$ & $4.3(7)$ & 4.1(7) & 4.6(11) \\
\hline & $\begin{array}{l}\text { Chinese countries } \\
(n=11)\end{array}$ & $2.7(3)$ & 4(4) & 4(1) & $3.5(4)$ & 1(1) & $3(4)$ & $4(5)$ & $4.5(4)$ & 4.4(8) \\
\hline \multirow[t]{2}{*}{ Facebook } & $\begin{array}{l}\text { Non-Chinese } \\
\text { countries }(n=16)\end{array}$ & $3.9(7)$ & 4.1(7) & $4(2)$ & 4.5(8) & $4(2)$ & $3.9(7)$ & $4(7)$ & $3.8(6)$ & 4.7(12) \\
\hline & $\begin{array}{l}\text { Chinese countries } \\
(n=11)\end{array}$ & $3.4(5)$ & $4.2(6)$ & 4(1) & $4.2(6)$ & 1(1) & $3.8(5)$ & $3.5(4)$ & $4.5(4)$ & 4.4(8) \\
\hline \multirow[t]{2}{*}{ Flickr } & $\begin{array}{l}\text { Non-Chinese } \\
\text { countries }(\mathrm{n}=16)\end{array}$ & $3(4)$ & $3(3)$ & $3(2)$ & $4.2(6)$ & $3.5(2)$ & $3(3)$ & $1.7(2)$ & $2.5(2)$ & $3.3(4)$ \\
\hline & $\begin{array}{l}\text { Chinese countries } \\
(n=11)\end{array}$ & 3.3(3) & $2.3(3)$ & 4(1) & $3.5(2)$ & 1(1) & $1.5(2)$ & $1.5(2)$ & 1(1) & $1.5(2)$ \\
\hline \multirow[t]{2}{*}{ Delicious } & $\begin{array}{l}\text { Non-Chinese } \\
\text { countries }(n=16)\end{array}$ & $1(1)$ & $2(2)$ & $3(1)$ & $2(2)$ & $3(1)$ & $3(1)$ & $3(2)$ & $3(1)$ & $3(2)$ \\
\hline & $\begin{array}{l}\text { Chinese countries } \\
(n=11)\end{array}$ & $1.3(3)$ & $1.7(3)$ & 1(1) & 1(1) & 1(1) & $1.7(3)$ & 2(3) & $1(1)$ & 2(3) \\
\hline \multirow[t]{2}{*}{ YouTube } & $\begin{array}{l}\text { Non-Chinese } \\
\text { countries }(n=16)\end{array}$ & $4.7(6)$ & $3.4(5)$ & $4(2)$ & 4.2(5) & $4(2)$ & $3.7(3)$ & $3.8(5)$ & $4(2)$ & 4(3) \\
\hline & $\begin{array}{l}\text { Chinese countries } \\
(n=11)\end{array}$ & $4(6)$ & $3.4(5)$ & $5(1)$ & 4(1) & 1(1) & $3(4)$ & $3.6(5)$ & 4(1) & $2.3(3)$ \\
\hline \multirow[t]{2}{*}{ RSS } & $\begin{array}{l}\text { Non-Chinese } \\
\text { countries }(\mathrm{n}=16)\end{array}$ & $3.7(3)$ & $3.7(3)$ & $4(2)$ & 4(3) & $4(2)$ & $4(2)$ & $4.3(3)$ & 4(3) & $4.7(6)$ \\
\hline & $\begin{array}{l}\text { Chinese countries } \\
(n=12)\end{array}$ & 2(3) & $2.3(3)$ & $1(1)$ & $2(2)$ & 1(1) & $2.7(3)$ & $2.7(3)$ & 4(3) & 4.1(7) \\
\hline \multirow[t]{2}{*}{ Twitter } & $\begin{array}{l}\text { Non-Chinese } \\
\text { countries }(\mathrm{n}=16)\end{array}$ & $3.2(5)$ & $4.2(6)$ & $4(2)$ & $4.2(6)$ & $4(2)$ & $4.2(5)$ & 4.2(5) & $4.2(5)$ & 4.8(11) \\
\hline & $\begin{array}{l}\text { Chinese countries } \\
(n=12)\end{array}$ & $2.8(4)$ & $3.5(4)$ & $3(1)$ & $3(2)$ & 1(1) & $2.7(3)$ & $3(4)$ & $4(2)$ & 4(5) \\
\hline \multirow[t]{2}{*}{ Wiki } & $\begin{array}{l}\text { Non-Chinese } \\
\text { countries }(n=16)\end{array}$ & $2(2)$ & $2.5(2)$ & $2.5(2)$ & $2.5(2)$ & $2.5(2)$ & $2.5(2)$ & $2.5(2)$ & $2.5(2)$ & $2.5(2)$ \\
\hline & $\begin{array}{l}\text { Chinese countries } \\
(n=12)\end{array}$ & $2.3(3)$ & $2.3(3)$ & 1(1) & 1(1) & 1(1) & $2.7(3)$ & $2.8(4)$ & $1(1)$ & $2(2)$ \\
\hline
\end{tabular}

Note:

(i) Participants rated according to the scale: $1=$ strongly disagree; $2=$ disagree; $3=$ neutral; $4=$ agree; $5=$ strongly agree.

(ii) Numbers in brackets, where shown, refer to the number of respondents who rate the usefulness of social media tools for library activity.

RSS feeds for outreach/inclusion activities, except only for book recommendations and library news posting activities. Flickr, on the other hand, was also rated low for most outreach/inclusion activities in both groups of countries. This might have been because of copyright issues and loss of exclusivity of a unique collection in a library, as stated by L3. These observations can be discerned from Table 6, which shows the mean ratings for perceived usefulness, wherein higher scores mean greater perceived usefulness of the tool.

\section{Administration of Library Policy for Inclusion}

Of the 28 libraries surveyed, only six (21\%) had library policies in place for inclusion, and two others had instituted guidelines. Library R7 (a public library) was the only one that had established a policy referred to as the social media policy and a mobile strategy, which stated the library's position with regard to social media tools. The same library was currently in the process of drafting what it called the social media strategy and social media guidelines "to enhance confidence for staff using social media on behalf of the Library", as reported by L7. Libraries R8 and R10 followed the inclusion policies of their respective governments.

The website http://www.trade.nsw.gov.au/policy/TIA-124 is a sample reference to R10's guidelines for posting blogs on the library site, which can be viewed by the public. R3 and R14 (as academic libraries) adopted their parent universities' guidelines, which L14 said was "with regard to usability, disability services and the like". L10 
and L15, on the other hand, mentioned that policies for social media technologies were currently being drafted.

\section{Benefits Realized and Challenges Faced}

This section reports on the benefits and challenges of using social media tools in libraries.

\section{Benefits of Using Social Media Tools in Libraries}

Table 7 shows that almost two-thirds (61\%) of the responses (17/28) indicated that reaching out to library users was the foremost benefit of using social media tools. The opportunity to engage users in an environment comfortable for patrons was considered a significant advantage. As stated by L11, social media helped the library to reach more users online "by putting content in spaces where customers interact”, while L5 said, "When done well, it (social media) allows us to connect with our users and build a relationship."

Five respondents (R4, R9, R20, R21 and R27) also opined that keeping up with the current technology and trends (such as in using social media tools) would reach more users, especially the younger generation, who are currently very much engaged with social media tools.

Another advantage of using social media, as reported by respondents, was that it could improve communications between libraries and the communities they serve. A prompt communication process with the library audience was regarded by six of the respondent libraries (R7, R9, R12, R19, R22 and R24) as a considerable benefit. Such communication enabled, in the words of L3, "immediacy of information transference”. In addition, four respondents (R17, R18, R23 and R27) reported that social media tools offered an interactive platform for two-way communication. This interactivity would "facilitate in gathering user feedbacks", as stated by R27, which was valuable "to improve library services and collections", as opined by R15.

According to six responses (R7, R12, R15, R19, R20 and R24), the use of social media tools in libraries was beneficial as it served as a mean of instant information dissemination for marketing and promoting library events, services, collection and facilities. This was evident when R7 stated that social media tools (e.g. Twitter and Facebook) had been used in the library for the promotion, development and delivery of library services. Above all, the low cost of the outreach efforts was considered to be an advantage (R10, R13 and R23).

\section{Challenges in Using Social Media Tools in Libraries}

Figure 1 illustrates the types of challenges expressed by the respondents when using social media tools in the academic and public libraries. A majority (59\%) of the participating libraries expressed issues relating to staff as a primary concern, which was indicated by the limited number of staff, lack of skills among the staff and the time needed for staff to manage and maintain the effort. This was evident when a participating public library, R10, noted, "many staff have been here 20-30 years and have little exposure to social media”. Staff training was highlighted as a key requirement in adapting to new technology environments that require frequent content updates and maintenance of services. An academic librarian, L4, indicated that the library was under-staffed and highlighted that,"it's just me who [is] doing all the social media effort". Although library staff lacked the necessary skills to manage the necessary upkeep of social media tools, L2 indicated that they self-educated themselves using online materials and sharing articles and information with others. Beside this, L7 indicated that "workshops for staff are probably very important ... to inform

Table 7: Benefits of using SM tools in libraries.

\begin{tabular}{lll}
\hline Benefits & Participating libraries & Responses \\
\hline Reaching out to library users & Academic libraries $(n=10)$ & R3, R4, R5, R14, R15, R20, R23, R24, R21, R27 \\
& Public libraries $(n=7)$ & R2, R8, R9, R10, R11, R12, R13 \\
Improve communication & Academic libraries $(n=7)$ & R6, R17, R18, R22, R23, R24, R27 \\
& Public libraries $(n=4)$ & R7, R9, R12, R19 \\
Promote library services & Academic libraries $(n=3)$ & $\mathrm{R} 15, \mathrm{R} 20, \mathrm{R} 24$ \\
& Public libraries $(n=3)$ & $\mathrm{R} 7, \mathrm{R} 12, \mathrm{R} 19$ \\
Low cost & Academic libraries $(n=1)$ & $\mathrm{R} 23$ \\
& Public libraries $(n=2)$ & $\mathrm{R} 10, \mathrm{R} 13$ \\
\hline
\end{tabular}




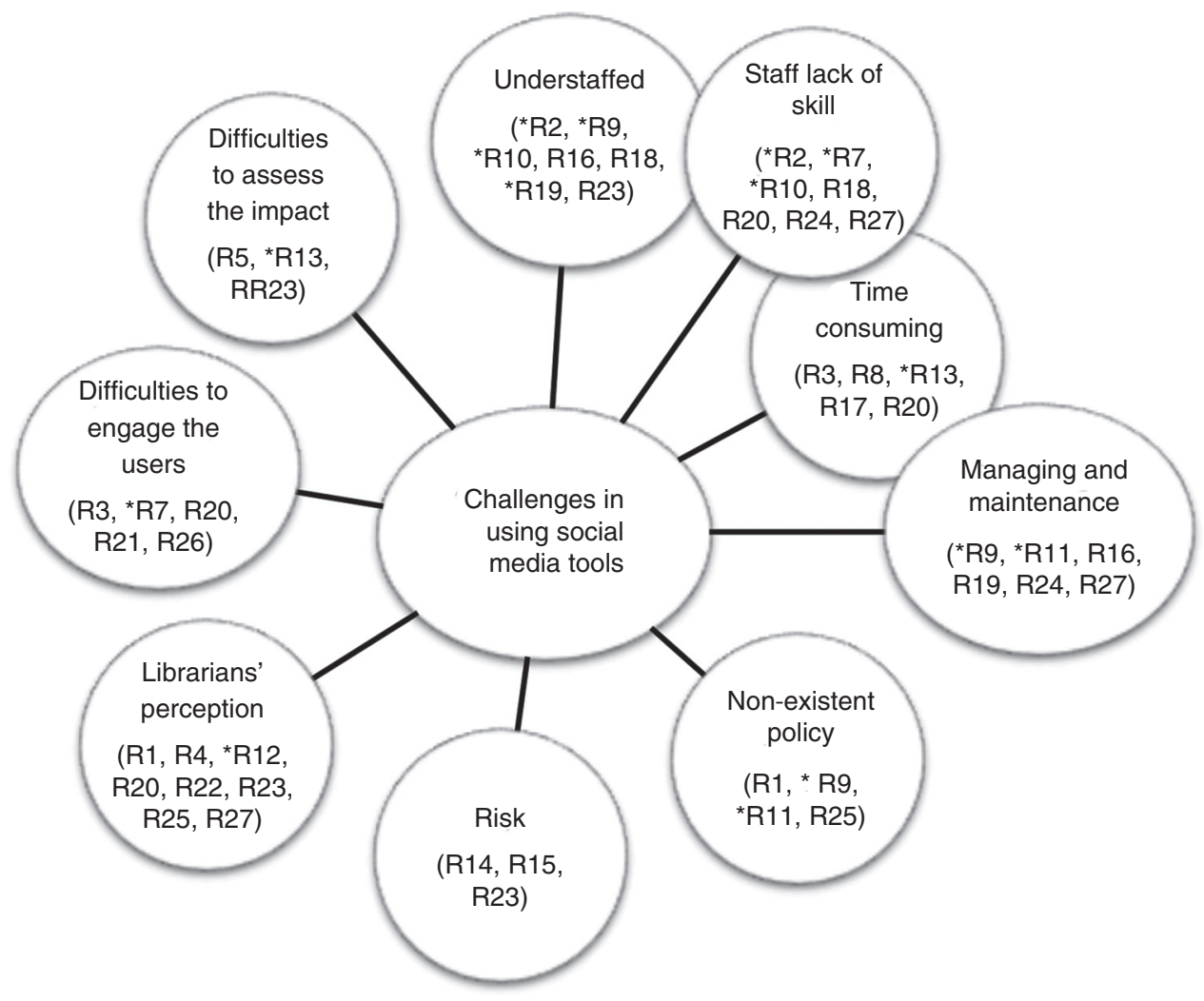

Figure 1: Challenges in using social media tools in libraries.

Note: *Responses from public libraries.

the staff how to use the social media tools and how social media can actually help them, how the social media tools work and support what they are doing. So currently we are conducting several workshops for this purpose. We'd like to do it more in the future."

A few participating libraries (R5, *R13 and 23) pointed out the difficulty in assessing the impact that such tools had on their audience and, hence, their inability to evaluate whether it was worth the cost, time and effort expended. As L7 highlighted, "we spent quite a lot of time assessing the benefit of using social media tools in the library."

An interesting challenge perceived by five participating libraries (R3, *R7, R20, R21 and R26) was the continuous need to update content to engage the interest of their capricious audience, who demanded instant results. R7 voiced a concern about the "on-going pressure to respond quickly and adapt to changing trends in the communications landscape". In addition, L7 highlighted the issue of "how to get people to access and to find out about the collection that the library has through social media tools".

Apart from the above challenges, the uptake of social media usage by the libraries was constrained by the librarians' own perceptions of, and concerns about, the tools themselves, such as the belief that students do not think of social media as an academic space (R4), the difficulty in attracting users' attention to the use of certain social media tools such as wikis (R20), concern about social media tools going out of fashion (R22), the need to invest a lot of effort (R23), the need to find out how to apply social media tools as the right means (R25) and the need to explore the best or the most suitable media for each service (R27). In addition, L7 opined that, "just because social media exists, this does not mean it is useful for the library. We need to assess the social media tools to see if they are suitable for the library." Additionally, three responses raised issues concerning the risks involved in using social media in the library, because the library was getting too many spam advertisements (R23), fears of invasion of privacy (R14) and unfair criticism or attacks (R15).

It is interesting to note one participating library's concern about its non-existing policy on social media usage in the library as stated by R11, who stated that the library should have developed a strategy and consistency of message that was disseminated through the social media tools and that, at the same time, provided 
a balance between allowing staff to create and explore social media and the sustainability of the practice and management of the platform. L2 also indicated that the". policy should present a good plan on how it is going to be maintained, and how are we going to use that tool to reach out to the public ... and then of course ... whether we have enough time to actually implement it." L4, on the other hand, added that there was a need for "policies or guides that could help the implementation into a move up process". Although respondents in both academic and public libraries (R1, R25, R9 and R11) reported that they had no existing policy for social inclusion and outreach, the libraries occasionally abided by the existing SM policies of their parent organizations (the university for academic libraries and country for public libraries), as evidenced by R3 and R14.

Overall, participants expressed positive sentiments regarding the adoption of social media tools for library activities. As R15 said,“Our social media outreach efforts have been a resounding success. Social media tools are particularly effective at reaching the youngest of our users: the undergraduates." However, the adoption of SM tools for inclusion/outreach activities in the libraries was in its early stages with expectation of better utilization in the future, as opined by five of the participant libraries (R1, R4, R8, R9 and R23). R9 noted that the use of social media is "a growing area of interest and our goals are to become more organized and methodical in our efforts".

\section{Discussion}

This section further discusses the research findings. Comparisons with other related studies are made, particularly concerning the use of social media for inclusion/ outreach activities, and the benefits of, and challenges involved in, using social media.

\section{Use of Social Media for Inclusion/Outreach}

The findings of this study affirm findings from earlier studies (Browne and Rooney-Browne 2008; Casey and Savastinuk 2006; Loudon and Hall 2010) showing that libraries had adopted inclusion/outreach activities such as library news posting, online library user guides, exhibitions and book recommendations for many years. In the present study, libraries had also employed social media tools as a part of their activities for at least 4 years.
However, it was found during the course of this research that, while RSS feeds were used extensively in many of the library activities, very few libraries used them for inclusion/outreach activities. This may present an opportunity for these libraries to extend existing and accepted service delivery platforms such as RSS feeds to develop their inclusion/outreach activities. In this respect, Tripathi and Kumar (2010) suggested several ways to improve the accessibility of RSS for library patrons (such as classifying RSS feeds for convenient access, making RSS feeds searchable for easy retrieval, providing instruction on how to use RSS and making RSS links available on the library homepage).

YouTube, on the other hand, appeared to be an immensely popular tool, especially for library tours, and it would seem logical to use it for other similar inclusion/ outreach activities that could be supported by this social media tool. In this study, the majority of the participants considered YouTube useful for storytelling. However, none of them had implemented it in their own libraries despite the potential of YouTube for supporting libraries' outreach activities. Alexander and Levine (2008) suggested that one of the applications of current social media tools could be in storytelling. Other than that, YouTube could be used to provide video guidance on how to use library catalogues, and how to access e-resources, databases and e-books. The range of social media tools used for inclusion/outreach programmes was limited primarily to Facebook, blogs and YouTube. The strengths of each tool would be better utilized if the most suitable one were chosen for each inclusion/outreach activity, keeping in mind the culture and needs of the people it serves. For example, RSS feeds and Twitter have the potential to be used for library news postings, blogs for book talks and recommendations, and Flickr for exhibiting collections or displaying events. The Flickr Creative Commons offers good directions on how to use Flickr, and it has provided the Smithsonian Museum with “... insights into how the knowledge, skills, and abilities of libraries, archives, and museums (LAM) can converge in the Web 2.0 environment to provide collection access to new, and in some cases unknown, audiences" (Kalfatovic et al. 2008, 267).

This study has also highlighted the underutilization of social bookmarking tools such as Delicious, wikis and Diego, in contrast to previous studies, which have shown the benefits of adopting them. A study of 48 academic libraries by Chu (2009) suggested that the wiki is a popular tool in university libraries. In addition, Tripathi and Kumar $(2010,204)$, who conducted a study on the use of Web 2.0 in 277 libraries, reported that the wiki could be 
used for resource listings, such as creating an "Alexander the Great" wiki, which lists the important websites and books in the library collection that are relevant to the topic. Green (2010) described the successful generic application of Delicious by librarians. There appears to be potential for libraries to learn from these experiences and promote the use of social tools for inclusion/outreach.

\section{Usefulness and Benefits}

In an overall analysis of data, libraries were categorized under two groups: (1) those located in Chinese-speaking countries/regions and (2) those in non-Chinese-speaking countries. It was found that Twitter was rated highly in the non-Chinese-speaking sample. While this finding may be attributed to sociocultural differences between the groups, it may be worthwhile to experiment with Twitter in libraries in Chinese-speaking countries, especially for library news postings. This study has established that connecting with people and building relationships with them are the primary benefits of using social media tools. This finding is consistent with those of other researchers who showed that social media supports relationships between users (Bolan, Canada, and Cullin 2007; Browne and Rooney-Browne 2008; Enders and Wineland 2012; Philips 2011; Riza Ayu and Abriah 2011). Vincent (2007, 4) emphasized that,"working in libraries is a job that should be all about connecting and linking, networking, communicating, solving problems, information-handling”. Given the characteristics of social media tools, it is likely that such technology will enhance library services, particularly in developing activities that accommodate the diversity of users, and will be able to reach new and current users outside the library.

\section{Overcoming Challenges}

This study has highlighted staffing issues as the primary concern for librarians in implementing social media tools. The lack of staff and the lack of ICT-skilled staff emerged as challenges in using social media. Librarians need to be well equipped in order to reach out to the communities they serve, especially to young patrons, who are heavily engaged with social media nowadays. There is a need for staff training and upgrading of skills.

While not all librarians can be adept at using social media tools, those who are not yet familiar with social media should familiarize themselves with the various uses of social media, so that they can formulate strategies to exploit these tools in order to reach out to the younger generation. In addition, initiatives should also be taken to address allocation of resources, and to define explicitly the roles and responsibilities highlighted in a library policy.

Library management, on the other hand, needs to recognize librarians' social media-uptake, as reported by Zohoorian-Fooladi and Abrizah (2014b). Librarians who are very well-versed in social media tools would be very keen to use these tools in library services for social inclusion and outreach programmes. On the other hand, librarians who are not well-acquainted with social media tools would need to be trained in the use of the tools in order to be equipped with the up-to-date trends.

Another challenge that was expressed by the respondents was the difficulty in assessing the effectiveness of using social media tools for outreach/inclusion activities. Chan (2012) conducted a study that investigated different advertising approaches through three campaigns in Facebook. The findings reported the impact of the different campaigns used in the outreach efforts through the number of clicks received and new fans attracted. However, insignificant results were reported to measure their impact with respect to publicity gained as opposed to the cost (money and staff).

Dennis (2012) reported a lack of studies that gauge the cost and success of outreach initiatives but suggested that an outcome-based approach could be used as a framework to assess the effectiveness of outreach initiatives, following the Association of College and Research Libraries "Standards for Libraries in Higher Education" (2011). Romero (2011) additionally opined that libraries could run a return on investment (ROI) analysis on the use of social media in their outreach/inclusion programmes. Although ROI is widely used to measure cost and revenue, in the context of libraries, which are nonprofit organizations, ROI can be used generally to measure and compare social media tools prior and post usage in outreach/inclusion initiatives in terms of consumption, user behaviour, and success or failure. In addition, this study also revealed that some participating librarians thought that students/library users were not receptive to incorporating social media in library services. This finding corroborates the findings of $\mathrm{Chu}$ and Meulemans (2008) and Burhanna, Seeholzer, and Salem (2009), which indicated that students were hesitant to use social media for academic purposes.

Above all, challenges to the uptake of social media in inclusion/outreach programmes in the participating libraries were closely related to the lack of policies on social media usage, which could address these 
challenges. The findings were also in line with a recent study conducted by Zohoorian-Fooladi and Abrizah (2014b), who reported the absence of social media policies as a barrier to the use of social media among academic libraries. In addition, Ismail Abidin, Kiran, and Abrizah (2013) also reported that the adoption of Web 2.0 applications in public libraries was not guided by any definite policies. Therefore, explicit policy directives need to be formulated. Moreover, library policies that direct an inclusive environment need to be developed. Such policies could promote the identification of marginalized and underserved user groups, and the implementation of activities that would enhance their participation in library activities.

Furthermore, existing policies on social media usage can restrict users and staff from using social media. This was evidenced by Tyler (2012), who reported that some libraries in Wales were blocking staff and students from accessing social media sites, while Charnigo and BarnettEllis (2007) reported a case of regulating access to Facebook in computer labs on campus, including the lab in the library in one university in the USA. Aiken (2006) reported prohibited access to MySpace in a public library in the USA. The employment of such policies is driven mainly by security and privacy issues following the organizations' policies of, for example, universities, public libraries and schools. However, some restrictions are only imposed for certain hours, such as access only permitted during lunch hours, or with a time limit, such as only for $1 \mathrm{~h}$. Other reasons for restricting access are (i) safeguarding the safety of children according to the Children's Internet Protection Act (USA), which requires K-12 schools and libraries in the USA to use an Internet filter and implement other measures to protect children from harmful online content in order to be eligible for federal funding; (ii) preventing the misuse or abuse of an organization's computers during working hours; (iii) blocking inappropriate content (e.g. libellous, offensive, phonographic, abusive or threatening materials); (iv) preventing student misconduct (e.g. cyberbullying) and (v) preventing students from being distracted from academic work (Ahn, Bivona, and DiScala 2011; Charnigo and Barnett-Ellis 2007; Tyler 2012).

In strategizing the implementation of social media in libraries, two approaches can be considered: a top-down and a bottom-up approach (Bawden et al. 2007). The topdown approach involves commitment from the library management to ensure the execution of the library's intended processes, which entails policy directives. Instituting specific policies for social media use can be a powerful tool to improve the library's services to promote inclusion/outreach. Alternatively the bottom-up approach is also called a user-driven or user-centric approach (Curran, Murray, and Christian 2007; Sodt and Summey 2009), in which users are involved collaboratively and interactively in library services, providing feedback, critical evaluation and playing a role as content provider, such as in wikis and social tagging/bookmarking tools. Because the bottom-up approach is less controlled and less structured, it could be challenged by some major security, privacy and misuse issues. Examples of these are the use of crackers to break into a websites when many interactive services are enabled, overexposure of personal information in the services and abuse of social media tools to disseminate spam and hate speech. The top-down approach, on the other hand, is a planned and systematic way of incorporating social media tools in libraries, providing more control and better organization. An ideal scenario would be one that involves both approaches in library services in order to strike a balance between providing user-driven services to reach out to users and controlling social media use by means of social media policies.

\section{Conclusion}

This paper reports on social media usage in libraries to enhance their inclusion and outreach activities. In general, the study showed academic and public libraries had already incorporated social media tools, and to some extent used them for inclusion/outreach activities. While these tools were deemed useful, only a few tools (e.g. wikis and social bookmarking tools) were currently in place. However, participants in this study indicated a general acceptance of the benefits of using social media and the inclination to apply them in the future. A mismatch seemed to exist between intention and actual execution though.

Libraries have an essential responsibility to contribute to social inclusion using outreach programmes as their instruments of delivery. Internet and communication technologies represent a potentially convenient means of achieving this goal. Social media tools seem to have become part of the routines of many people, especially the young. This provides opportunities for libraries to adopt social media platforms strategically to reach out to the communities they serve. The use of social media can help build the image of a library. However, when methods are ill-defined or the tools improperly applied, it could prove detrimental to that image. In 
such cases, the use of social media tools should be streamlined and optimized, the roles and responsibilities of stakeholders clarified, objectives defined and the execution of social media as a means of promoting social inclusion enhanced. All this can be done through institutionalizing specific policies on the use of social media tools in libraries using either the top-down or a bottomup approach as discussed above. However, this exploratory study has revealed a lack of specific policies that clarify the responsibilities of libraries in promoting social inclusion. This is possibly something libraries can give some thought to.

This study is limited by a small sample size, so generalization of the results should be treated with caution. The findings, nevertheless, can motivate future research in this area. Because this study employed a survey and a limited interview session as the research methods, further work such as content analysis on the social media pages of libraries could be conducted to gather in-depth information and obtain a better understanding of the use of social media tools for inclusion and outreach activities in libraries.

Acknowledgement: The authors would like to acknowledge Mrs Aruna Bhasker for her assistance in data checking to confirm the data accuracy.

\section{References}

Ahn, J., L. K. Bivona, and J. DiScala. 2011. "Social Media Access in K12 Schools: Intractable Policy Controversies in an Evolving World." Proceedings of the American Society for Information Science and Technology 48 (1): 1-10.

Aiken, J. 2006. “Hands Off MySpace." American Libraries 37 (7): 33. Alexander, B., and A. Levine. 2008. "Web 2.0 Storytelling: Emerging of a New Genre." Educause Review 43 (6): 40-56.

Association of College and Research Libraries. 2011. "Standard for Libraries in Higher Education.” Accessed July 7, 2014. http:// www.ala.org/acrl/sites/ala.org.acrl/files/content/standards/ slhe.pdf.

Bawden, D., L. Robinson, T. Anderson, J. Bates, U. Rutkauskien, and P. Vilar. 2007. "Towards Curriculum 2.0: Library/Information Education for a Web 2.0 World." Library and Information Research 31 (99): 14-25.

Bolan, K., M. Canada, and R. Cullin. 2007. "Web, Library, and Teen Services 2.0." Young Adult Library Services 5 (2): 40-43.

Browne, A., and C. Rooney-Browne. 2008. "Punching above Our Weight: A Small Scottish Library Service joins the Global Community." Paper presented at the World Library and Information Congress: 74th IFLA General Conference and Council, August 10-14, Quebec, Canada. Accessed December 22, 2014. http://archive.ifla.org/IV/ifla74/papers/159Browne_Rooney-Browne-en.pdf.
Burhanna, K. J., J. Seeholzer, and J. Salem, Jr. 2009. "No Natives Here: A Focus Group Study of Students Perceptions of Web 2.0 and the Academic Library." International Information and Library Review 35 (6): 523-532.

Bury, L. 2013. "Library Campaigners Predict 1,000 Closures by 2016." The Guardian, July 12. Accessed July 7, 2014. http:// www.theguardian.com/books/2013/jul/12/librarycampaigners-1000-closures-2016.

Carter, T. M., and P. Seaman. 2011. "The Management and Support of Outreach in Academic Libraries." Reference and User Services Quarterly 51 (2): 163-171.

Casey, M. E., and L. C. Savastinuk. 2006. "Library 2.0: Service for the Next-Generation Library." Library Journal 131 (14): 40-43.

Chan, C. 2012. "Marketing the Academic Library with Online Social Network Advertising." Library Management 33 (8-9): 479-489.

Charnigo, L., and P. Barnett-Ellis. 2007. "Checking Out Facebook. com: The Impact of a Digital Trend on Academic Libraries." Information Technology and Libraries 26 (1): 23-34.

Chu, S. K.-W. 2009. "Using Wikis in Academic Libraries." The Journal of Academic Librarianship 35 (2): 170-176.

Chu, S. K.-W., and H. S. Du. 2013. "Social Networking Tools for Academic Libraries." Journal of Librarianship and Information Science 45 (1): 64-75.

Chu, M., and Y. N. Meulemans. 2008. "The Problem and Potential of MySpace and Facebook Usage in Academic Libraries." Internet Reference Services Quarterly 13 (1): 69-85.

Connell, R. S. 2009. "Academic Libraries, Facebook and MySpace, and Student Outreach: A Survey of Student Opinion." Portal: Libraries and the Academy 9 (1): 25-36.

Curran, K., M. Murray, and M. Christian. 2007. "Taking the Information to the Public through Library 2.0." Library Hi Tech 25 (2): 288-297.

Dennis, M. 2012. "Outreach Initiatives in Academic Libraries, 20092011.” Reference Services Review 40 (3): 368-383.

Dickson, A., and R. P. Holley. 2010. "Social Networking in Academic Libraries: The Possibilities and the Concerns." New Library World 111 (11): 468-479.

Enders, N. R., and H. Wineland. 2012. "Writing a Social Media Policy for your Library." Kentucky Libraries 76 (1): 16-19.

Flood, A. 2012. "UK Lost More than 200 Libraries in 2012." The Guardian, December 10. Accessed July 7, 2014. http://www. theguardian.com/books/2012/dec/10/uk-lost-200-libraries2012.

Gravetter, F. J., and L-A. B. Forzano. 2008. Research Methods for the Behavioral Sciences. Stamford, CT: Cengage Learning.

Green, C. 2010. "Tag! You're It! Experiencing Delicious.com at Your Library - Introduction to Social Bookmarking." Kentucky Libraries 74 (1): 4-8.

Huang, H., S. K-W. Chu, and D. Chen. In press. "Interactions between English-Speaking and Chinese-Speaking Users and Librarians on Social Networking Sites." Journal of the American Society for Information Science and Technology. Accessed December 22, 2014. doi:10.1002/asi.23251.

Ismail Abidin, M., K. Kiran, and A. Abrizah. 2013. "Adoption of Public Library 2.0: Librarians' and Teens' Perspective.” Malaysian Journal of Library and Information Science 18 (3): 75-90.

Kalfatovic, M. R., E. Kapsalis, K. P. Spiess, A. Van Camp, and M. Edson. 2008. "Smithsonian Team Flickr: A Library, Archives, and Museums Collaboration in Web 2.0 Space." Archival Science 8 (4): 267-277. 
Kavner, L. 2011. "Library Budget Cuts Threaten Community Services Across Country." Huffington Post, November 16. Accessed July 7, 2014. http://www.huffingtonpost.com/2011/11/16/canthe-american-library-_n_1096484.html?utm_hp_ref=librariesin-crisis.

Kelly, B., P. Bevan, R. Akerman, J. Alcock, and J. Fraser. 2009. Library 2.0: Balancing the Risks and Benefits to Maximise the Dividends. Program 43 (3): 311-327. Accessed March 16, 2013. doi:10.1108/00330330910978608.

Kroski, E. 2007. "The Social Tools of Web 2.0: Opportunities for Academic Libraries.” Choice 44 (12): 2011-2021.

Loudon, L., and H. Hall. 2010. "From Triviality to Business Tool: The Case of Twitter in Library and Information Services Delivery." Business Information Review 27 (4): 236-241.

Mack, D., A. Behler, B. Roberts, and E. Rimland. 2007. "Reaching Students with Facebook: Data and Best Practices." Electronic Journal of Academic and Special Librarianship 8 (2): 4.

Mathews, B. S. 2006. "Do You Facebook? Networking with Students Online." College and Research Libraries News 67 (5): 306-307.

Milstein, S. 2009. "Twitter for Libraries (and Librarians)." Computers in Libraries 29 (5): 17-18.

Muddiman, D., S. Durrani, J. Pateman, M. Dutch, R. Linley, and J. Vincent. 2001. "Open to All? The Public Library and Social Exclusion: Executive Summary.” New Library World 102 (4): 154-158.

Nahid Bayat, B., and A. N. Zainab. 2013. "Examining the Accessibility and Facility for the Disabled in Public and University Library Buildings in Iran." Information Development 29 (3): 241-250.

Nahid Bayat, B., A. N. Zainab, and N. Abdullah. 2014. "Student Volunteers as Academic Saviours and Social Connectors among the Visually Impaired in an Academic Library." International Journal of Libraries and Information Services 64 (1): 40-48.

Phillips, N. K. 2011. "Academic Library Use of Facebook: Building Relationships with Students." The Journal of Academic Librarianship 37 (6): 512-522.

Riza Ayu, A. R., and A. Abrizah. 2011. "Do You Facebook? Usage and Applications of Facebook Page among Academic Libraries in Malaysia." International Information and Library Review 43 (3): 239-249.
Romero, N. L. 2011. "ROI: Measuring the Social Media Return on Investment in a Library." The Bottom Line: Managing Library Finances 24 (2): 145-151.

Sekyere, K. 2009. "Too Much Hullabaloo about Facebook in Libraries! Is It Really Helping Libraries?” Nebraska Library Association Quarterly 40 (2): 22-27.

Sodt, J. M. and T. P. Summey. 2009. "Beyond the Library's Walls: Using Library 2.0 Tools to Reach Out to All Users." Journal of Library Administration 49 (1-2): 97-109.

Train, B., P. Dalton, and J. Elkin. 2000. "Embracing Inclusion: The Critical Role of the Library." Library Management 21 (9): 483-491.

Tripathi, M., and S. Kumar. 2010. "Use of Web 2.0 Tools in Academic Libraries: A Reconnaissance of the International Landscape." International Information and Library Review 42 (3): 195-207.

Tyler, A. 2012. "Welsh Libraries and Social Media: A Survey 2012." Ariadne 68. Accessed July 6, 2014. http://www.ariadne.ac.uk/ issue68/tyler.

United Kingdom. 1999. "Department for Culture, Media and Sport (DCMS)."Libraries for All: Social Inclusion in Public Libraries; Policy Guidance for Local Authorities in England. London: Department for Culture, Media and Sport. Accessed March 16, 2013. http://webarchive.nationalarchives.gov.uk/ + /http:// www.culture.gov.uk/Reference_library/Publications/ archive_1999/lib_soc_inclusion.htm.

United Nations. 1995. Report of the World Summit for Social Development, Copenhagen, 6-12 March. Sales No. E. 96.IV.8. Accessed March 16, 2013. http://www.un.org/esa/socdev/ wssd/index.html.

van Winden, W. 2001. "The End of Social Exclusion? On Information Technology Policy as a Key to Social Inclusion in Large European Cities." Regional Studies 35 (9): 861-877.

Vincent, J. 2007. "Social Exclusion - Where Is It Going?" Information for Social Change 26: 3-7. Accessed December 22, 2014. http://www.libr.org/isc/issues/ISC26/articles/26\%20Social\% 20exclusion\%20where\%20is\%20it\%20going.pdf.

Zohoorian-Fooladi, N., and A. Abrizah. 2014a. "Academic Librarians and their Social Media Presence: A Story of Motivations and Deterrents." Information Development 30 (2): 159-171.

Zohoorian-Fooladi, N., and A. Abrizah. 2014b. "Personifying Academic Librarians Social Media Presence.” Malaysian Journal of Library and Information Science 19 (3): 13-26. 
Copyright of Libri: International Journal of Libraries \& Information Services is the property of De Gruyter and its content may not be copied or emailed to multiple sites or posted to a listserv without the copyright holder's express written permission. However, users may print, download, or email articles for individual use. 